Research Article

\title{
The Nexus between Socio-Economic Environment and Recurrence of Inter-Ethnic Conflicts In Nyakach and Sigowet Sub-Counties of Western Kenya
}

\author{
James Omondi Juma ${ }^{1}$ Prof. Crispinous Iteyo ${ }^{2}$ Dr. Ruth Simiyu ${ }^{3}$ \\ ${ }^{123}$ Departments of Peace and Conflict Studies, Masinde Muliro University of Science and Technology \\ P.O BOX, 190-50100 Kakamega, KENYA
}

\begin{abstract}
The recurrence of inter-ethnic conflicts is mainly attributed the socio-economic constraints and deprivations that make disgruntled communities turn against one another in the efforts to get the kind of services they believe that they deserve. This is a common phenomenon globally and also in Kenya. There are a number of social and economic issues surrounding inter-ethnic conflicts in Nyakach and Sigowet Sub-counties of Western Kenya that have made communities get involved in the inter-ethnic conflicts regularly. The study investigated the nexus between the socio-economic environment and recurrence of inter-ethnic conflicts in Nyakach and Sigowet Sub-counties of Western Kenya. The study aim at examining the relationship between the socio-economic environment and the recurrent inter-ethnic conflicts in area of study. The results of the study therefore, show the connection between following socio-economic factors and conflicts; the socio-economic activities, distribution of economic resources and opportunities, Politicization of ethnicity and political exclusion, socio-cultural perceptions and Stereotypes, and the socio-economic drivers of conflicts including poverty, youth unemployment, ethnic mistrust and land and boundary issues.
\end{abstract}

Key words: Recurrence of conflict, Socio-economic environment, Inter-ethnic conflicts

\subsection{Introduction}

Recurrent inter-ethnic conflicts in Kenya is linked to competition for scarce natural resources, cultural rivalry and cultural identities as well as political activities (Oucho, 2008). There have been sporadic cases of inter-ethnic clashes in Nyakach and Sigowet sub counties for the past three decades that have caused humanitarian crisis in the area (Akinyi-Dar et al., 2011; Nyongesa et al., 2016). Geopolitics and political activities have further complicated the conflict situation in Nyakach and Sigowet Sub counties (Akinyi-Dar et al., 2011). Politically instigated conflicts have been witnessed in the area in 1992-1993, 1997, and 2008 (Oucho, 2008).

The government has attempted to curb cattle rustling basedconflict, through the establishment of Anti-Stock Theft Police Unit in the region, which has not yielded much in stopping the menace (Akinyi-Dar et al., 2011). Government institutions like NSC, NCIC have also been working with NGOs and local CSOs and communities through DPCs to bring about lasting peace (UNDP, 2013; Akinyi-Dar et al., 2011, Safer World Briefing, 2015). Some of these efforts, helped in averting potential conflicts. For instance, before and during the 2013 general elections, the Safer World in collaboration with Local Capacities for Peace International (LPCI) assisted in the formation of Peace and Security Task Team. The team was mainly mandated with monitoring the election process, collecting and sharing early warning information as well as responding to conflict risk that arose in Nyakach and Sigowet Sub-counties (Does, 2013). The Committee was formed in consultation with members of the community, the provincial administration, peace committee members, youth groups, civil society organisations, council of elders, the police and the media. The committee shared their views and ideas on the role and function of the peace and security forum (Does, 2013). These initiatives helped avert the looming conflict in the area during the 2013 general elections. Studies have shown that when people face social injustices including socio-economic inequalities, they are at the risk of engaging in harmful antisocial behaviours including violence and crime (Brown \&Stewart, 2015). The increasing human population coupled with other challenges such as increased competition for scarce resources and high levels of poverty are likely to further complicate the conflict situation in Nyakach and Sigwet subcounties. Therefore, based on the socio-economic situation in Nyakach and Sigowet Sub-counties, there was need to conduct a study to unearth information on the recurrence of interethnic conflicts in relation to the nexus between socioeconomic environment and recurrence of conflicts in the area. This is because, despite several initiatives by government, civil society organizations and various leaders to bring about lasting peace in the area, the conflicts have kept on recurring in the area over the years.

\subsection{Theoretical Framework}

This study was guided by John Burton's (1990) human needs theory. Burton has been applying this theory more actively to emerging political and social conflicts. In his work on protracted, social conflicts, he looked at how universal human needs often are neglected, making groups to resort to the use violence to claim their rights and meet their needs. In what is considered a compatibility of human needs, Burton opines that education and culture make parties manipulate issues and dehumanize the other parties (Burton, 1990). In Burton's view, the most salient needs to understanding destructive social conflicts include the needs for recognition, identity, personal 
James Omondi Juma et al / The Nexus between Socio-Economic Environment and Recurrence of Inter-Ethnic Conflicts In Nyakach and Sigowet Sub-Counties of Western Kenya

development and security. However, over time, he emphasized the failure of existing state systems to meet the need for identity as the primary cause of modern ethno-nationalist conflicts. The theory was used to understand how the deprivation of human needs influences the recurrence of interethnic conflicts in Nyakach and Sigowet sub counties. The theory was also useful in understanding the root causes of the conflicts in Nyakach and Sigowet Sub counties.

The independent variable which is social,-economic environment is the key determinant of the situation in the community. The socio-economic environment informs in the needs of the community and how they have been met. By analyzing the socio-economic environment, the researcher is also able to tell what is missing that need to be addressed and which if not properly addressed can lead to the recurrence of inter-ethnic conflicts in the study area. Recurrence of interethnic conflicts is the dependent variable because it is affected by social-economic environment. Depending on how effective needs are addressed in the socio-economic environment is, there can be positive outcome which can lead to sustainable peace however if the interventions are weak then, the recurrence of ethnic conflicts are likely to persist.

\subsection{Methodology}

The researcher employed descriptive research design in this study. The research was conducted in Sigowet Sub-county of Kericho County and Nyakach Sub-county of Kisumu County. In this Study, Nyakach and Sigowet Sub counties were purposively selected due to the magnitude of the recurrence of inter-ethnic conflicts within the area (Red Cross, 2014; Safer World Briefing, 2015). The study was conducted in eight sublocations, simple random sampling was used to select the 8 sub-locations out of the 27 sub-locations.

The target population for the study was 11,037 , in this regard therefore, since the target population is greater than 10000, the desired sample population was determined using Fisher's formula for sample size determination (Fisher et al., 1983 cited in Mugenda \& Mugenda, 1999:43). The formula is stated below.

$$
\mathrm{n}=\frac{z^{2} p q}{d^{2}}
$$

Where $\mathrm{n}=$ desired sample size (the target population is greater than 10,000).

$\mathrm{z}=$ the standard normal deviate at the confidence level of $95 \%$ is 1.96 .

$\mathrm{p}=$ the proportion of the target population estimated to have characteristics being measured is set at $50 \%$

$$
\begin{aligned}
& \mathrm{q}=1-\mathrm{p} \text { (probability of non-success) } \\
& \mathrm{d}=\text { level of statistical significance set at } 0.05 \\
& \mathrm{n}=\frac{(1.96)^{2} * 0.5 *(1-0.5)}{(0.05)^{2}} \\
& \mathrm{n}=384
\end{aligned}
$$

The sample population of 384 respondents was distributed as follows; 38 government officials were purposively sampled, 10 Non-state actors were purposively sampled and convenience sampling was used for 40 respondents in four Focus Group Discussions (10 respondents per FGD). Stratified proportionate sampling was used for 296 household heads.

The study employed both probability and non-probability sampling methods. Quantitative data was collected using questionnaires while qualitative data was collected through interview guides and FGD guides. Both primary and secondary data were utilised during the study. Quantitative data was analysed using SPSS version 17 and MS Excel software to obtain descriptive statistics particularly frequencies and percentages and qualitative data was analysed using thematic techniques to support quantitative data. Quantitative data was presented using tables, graphs, and charts while qualitative data was presented inform of narrative reports and verbatim quotations.

\subsection{Study Findings}

\subsection{The Economic Activities in Nyakach and Sigowet Sub-} counties

The study sought to establish the common economic activities from the household heads in Nyakach and Sigowet Subcounties. The results were as indicated in Figure 4.1.

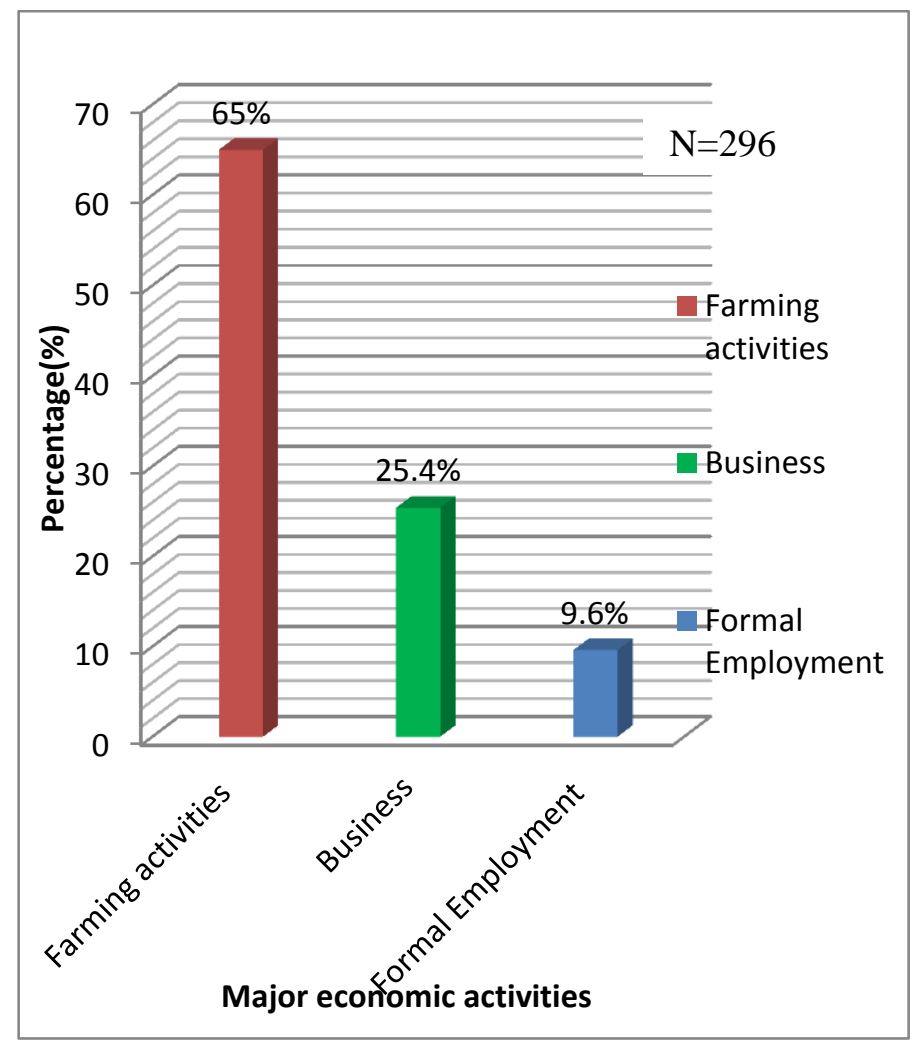

Figure 4.1: Economic Activities in Nyakach and Sigowet Sub-counties of Western Kenya

Source: Field Data, 2017

The findings from the study revealed that out of the 296 households, $192(65 \%)$ identified farming activities as the major economic activity in the area, $75(25.4 \%)$ identified business as the major socio-economic activity while 29 (9.6\%) identified employment as the major means of subsistence. The results from the households were consistent with the results from key informants who also indicated that farming was a major economic activity in the area. In an interview with the official from World Vision, the official reiterated that farming was the back bone of the economy and a major source 
James Omondi Juma et al / The Nexus between Socio-Economic Environment and Recurrence of Inter-Ethnic Conflicts In Nyakach and Sigowet Sub-Counties of Western Kenya

of livelihood for the residents of the Nyakach and Sigowet sub-counties.

In support of this, the Sub-county administrators from both Nyakach and Sigowet sub-counties also indicated that there was a lot of farming that was going on in the area. The Nyakach Sub-county administrator opined that:

In this sub-county, farming is a major activity with many residents being agro-pastoralist. In almost every family people keep livestock and are also engaged in crop farming. We also have people who do poultry farming and those who grow sugarcane in some areas. Most people however engage in livestock rearing and food crop farming (Nyakach Sub-county administrator, $20^{\text {th }}$ March 2017).

In another interview the Soin/Sigowet Sub-county

Administrator signposted that;

Farming is the most important economic activity in this area; many people have farms where there are a lot of agricultural activities going on. Farming activities here include; livestock keeping which is important as people have a lot of attachment to the cows for milk production. We also have people grow food crops. There are also a number of tea bushes in the location. Another common farming activity is the leasing of farms which people with large trucks of land do at a fee (Soin/Sigowet Sub-county Administrator, 10 ${ }^{\text {th }}$ April 2017).

The results from FGDs conducted in Cherwa also revealed farming as the major source of livelihood in the study area. The FGD participants indicated that the both livestock rearing and crop farming were important economic activities to the residents of the area.

Apart from Agriculture, it emerged from the FGDs conducted in Sondu market that business was an important economic activity in the area. The FGD participants enumerated common business activities in the area to be including sale of farm produce, people running small shops, young men riding motorcycles and other common trading activities from various parts of the two sub-counties as well as other areas including Homa bay and Kisii counties. The FGD participants in Sondu indicated that the Sondu market was an important market place that connected people from Kericho, Kisumu and Kisii counties for trade and other business.

The study also revealed that majority of the respondents from the household heads were not in any formal employment. In this case gainful employment meant on formal employment which gives them a regular monthly salary as well as other related benefits such as pension, health insurance. There are also people who work as casual farm labourers, sugar cane cutters locally known as Obanda, tea pickers, sand harvesters and fishermen. All these are form part of economic activities in the study area.

An interview with a Kenya Redcross official revealed that the frequent ethnic conflicts and tension from these conflicts have a huge impact on the economic activities in the area. The official further opined that cattle rustling the major conflict trigger in the Area. The Luo from Nyakach and the Kipsigis from Sigowet sub-county both Cherish agriculture and specifically livestock rearing as an economic activity, therefore stealing of livestock obstructs people livelihoods and can be a cause for mobilization among members of either community to retaliate.

During the periods of these conflicts or tension following these conflicts, other economic activities such as trade are greatelely impacted. During violent periods people neither attend to their farms nor go to the market to earn their incomes which negatively affects the economic status of the residents. As it emerged in the chapter four, one of the impacts of these frequent conflicts is burning of shelters which include burning of food stores thereby affecting people's subsistence as was signposted by one of the respondents from the Tabaita FGD.

The fact that crop farming and livestock rearing are the major economic activities in the area therefore gives an indication that there is a lot of pressure on land and the need for livestock as the key source of wealth among residents of the two subcounties. The Kipsigis' cultural practice of cattle rustling therefore can be credited for the incessant recurrent conflicts in the area. These findings are in agreement with Kipkemoi (2015) whose study in Kuresio Sub-county found out that most ethnic conflicts revolved around land for agriculture and cattle rustling as major economic activities among residents as less than 20 per cent of the residents were involved in formal employment.

\subsection{Distribution of Economic Resources and Opportunities as a cause of conflicts in Nyakach and Sigowet Sub- counties of Western Kenya}

The study sought to find out whether distribution of economic resources and opportunities was cause of conflicts in the study area. The results from household heads are as shown in Figure 4.2 .

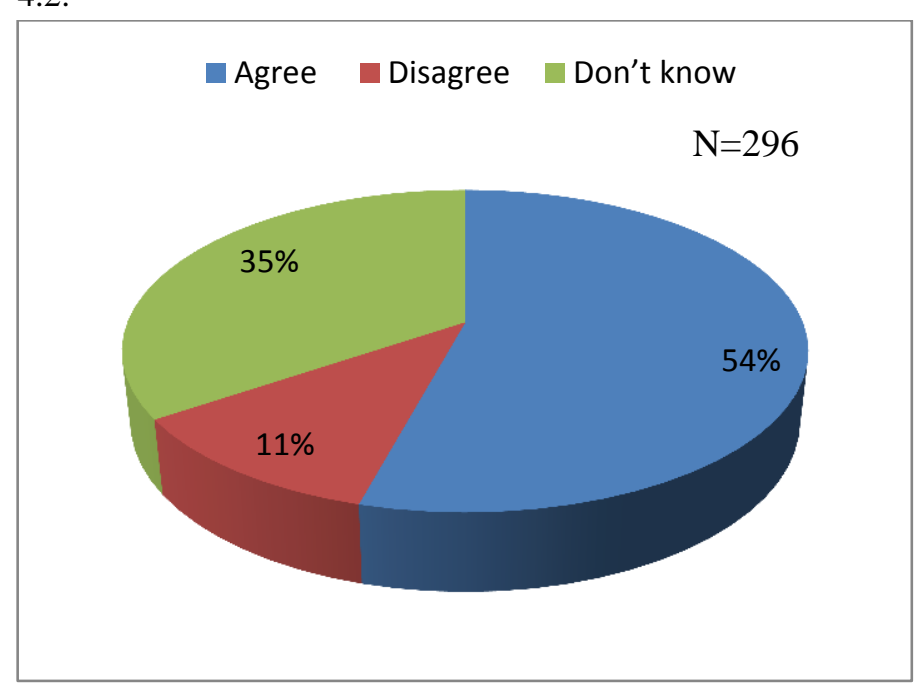

Figure 4.2: Distribution of economic resources and opportunities cause conflicts in Nyakach and Sigowet Subcounties of Western Kenya

Source: Field Data, 2017

The results in Figure 4.2 revealed that 160 (54\%) of the respondents agreed that distribution of economic resources and opportunities was a cause of conflicts in the study area as compared to $32(11 \%)$ who did not agree and 103 (35\%) who indicated that they did not know.

In support of the findings from household heads, the key informants gave opinions on the issue of distribution of the 
James Omondi Juma et al / The Nexus between Socio-Economic Environment and Recurrence of Inter-Ethnic Conflicts In Nyakach and Sigowet Sub-Counties of Western Kenya

economic resources and opportunities as a cause of conflicts. During an interview the Sigowet Ward MCA indicated that;

I agree that distribution of resources can be a cause of conflicts. Cases of conflicts are especially common where there is inequality in distribution of resources and opportunities. Our government has however done well by introducing Uwezo fund for the youths and women to access capital and get empowered economically (Sigowet Ward MCA, $15^{\text {th }}$ March 2017).

In contrast the South East Nyakach MCA indicated that;

One of the biggest problems we have with the youths in our area is unemployment. Many young people complete school, some are even graduates but since they cannot get jobs, some of them end up in crime and other activities that compromise on the peace in this area. The biggest problem that has always caused conflicts in our border with the Kipsigis is this habit of cattle theft. Majority of the people involved are the unemployed youths. If these youths can get equality in employment then we cannot have such problems. Many of our youths have also joined the boda boda business, but there is still this problem of other youths attacking them and in some cases even killing them just to take away their motorcycles. To me all these are happening because the government is not doing enough to empower the youths in this area (South East Nyakach Ward MCA, April 10 ${ }^{\text {th }}$ 2017).

Further during an interview, an official of the Kericho youth Bunge signposted that;

As youths we are disadvantaged, even the county governments that were supposed to be helpful in increasing the number of opportunities for us have become family business where tenders and jobs are given to people on the basis of favouritism and nepotism. There is indeed inequality in sharing of opportunities which has made many youths desperate to get any means of subsistence that they can access and these means can include activities that can jeopardize peace (Interview with an official of the Kericho Youth Bunge, $22^{\text {nd }}$ April 2017).

During the Cherwa FGD one of the participants opined that;

In this area accessing opportunities is a big problem; even accessing education bursaries for our children is a challenge as people in those positions are more interested in serving their personal interest. There is no consideration for poor people; corruption has made poor people suffer the most (Cherwa FGD participant, $9^{\text {th }}$ April 2017).

From the results it is evident that there are serious concerns on the distribution of economic resources and opportunities. These concerns and perceived inequalities may lead to conflicts especially in situations where the feeling of discrimination in the distribution of these economic resources is shared across an ethnic group.

These findings are in agreement with Kipkemoi (2015) who opined that conflicts emanate from the incidence of inequality, specifically, economic inequality. The results further concur with Bahgat, et al (2017) who contended that when there is a gap of prejudice between what people feel they merit to have and what they get in terms of goods and economic power, dissatisfied people will join together and rebel thereby causing conflicts. The findings of this study are also in agreement with Stewart \& Brown (2015) who indicate that economic inequality provides a strong incentive for group mobilization due to strong feelings of marginalization and the need for economic empowerment. The results are further supported by Gur (1970) who maintained that that collective sense of displeasure with the predominant dissemination of material goods in society, and a perceived disparity in rising wealth versus individual living standards are a reason for resentment against the state and eventual conflicts in the society.

From the foregoing, it is evident that ethnic conflicts are influenced largely by the distribution of economic resources and opportunities. People who feel disenfranchised by the sharing of these resources and opportunities may therefore vent their frustration on those around them whom they perceive to be beneficiaries of these perceived social injustices. In this case the ethnic identity tends to appeal to the emotions of the people and feelings of collective discrimination by people from the same ethnic group may make them look at another ethnic group as an enemy due to the feeling that they benefit from a system that has denied their ethnic group economic opportunities.

\subsection{Politicization of Ethnicity and Political Exclusion as Contributors to Conflicts in Nyakach and Sigowet Sub- counties of Western Kenya}

The study sought to find out whether politicization of ethnicity and political exclusion contributed to conflicts in the study area. The results are as indicated in Figure 4.3

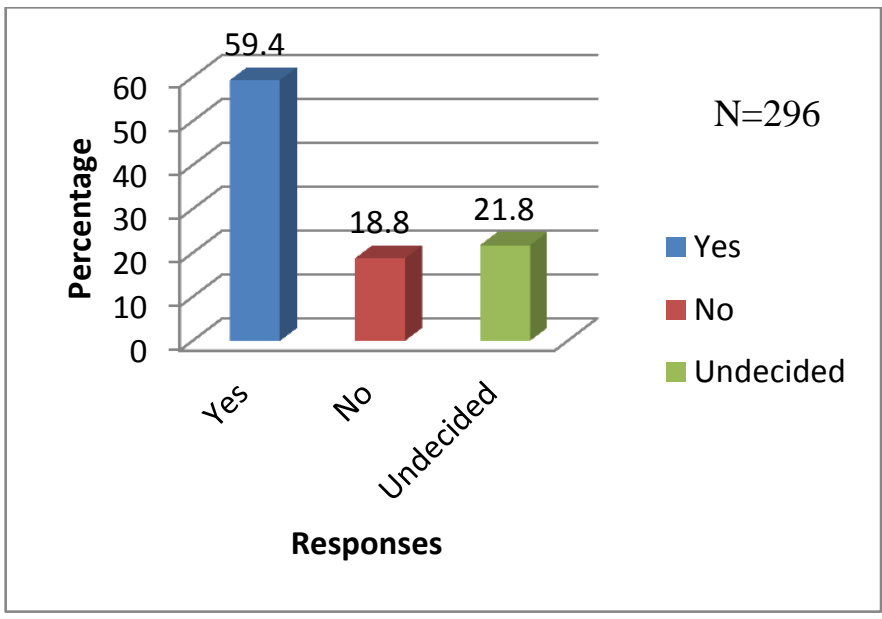

Figure 4.3: Politicization of ethnicity and Political exclusion contributes to conflicts in Nyakach and Sigowet Sub-counties of Western Kenya

\section{Source: Field Data, 2017}

The results in Figure 4.3 indicate that out of the 296 household heads $176(59.4 \%)$ agreed that that politicization of ethnicity and political exclusion contributed to conflicts as compared 56 $(18.8 \%)$ who were of the contrary opinion and $65(21.8 \%)$ who were undecided.

The results were supported by findings both from the FGD and Key informant interviews. The results from interviews by the two MCA from Sigowet Ward and South East Nyakach 
James Omondi Juma et al / The Nexus between Socio-Economic Environment and Recurrence of Inter-Ethnic Conflicts In Nyakach and Sigowet Sub-Counties of Western Kenya

ward exposed that politics had a lot of influence on the recurrence of conflicts in the study area. The MCAs contended that there was a tendency by local political players to use ethnicity to whip up emotions in order to draw political support especially when it came to national politics; this raised a lot of tension in the area.

The Sigowet Sub-county Administrator opined that;

Before devolution we had these issues of exclusion coming out strongly and it was indeed a cause of dissatisfaction as people felt left out of government. In the new dispensation we do not need to have conflicts over issues of inclusivity because devolution has brought government closer to the people and all 47 counties get their share of devolved funds. All we need is issue based politics and not ethnic politics that has caused division all these years (Soin/Sigowet Sub-county Administrator, $10^{\text {th }}$ April 2017).

The findings from FGD were also in support of the findings from the household heads. In the Cherwa FGD 8 out of 10 participants agreed that politicization of ethnicity and political exclusion contributed immensely to the conflicts. One of the participants in the FGD signposted that;

Kenyan politics is largely ethnic in nature; people vote leaders along ethnic lines. In this region for example, it is known that the Luos support ODM while the Kipsigis support the Jubilee party. In fact now that we are approaching the August elections there is a lot of tension between ODM supporters and Jubilee supporters in this area. People fear that in case of any national fallout, this area can be gravely affected just as it has been happening in all electioneering periods since 1992 (Tabaita FGD participant, 20 ${ }^{\text {th }}$ April 2017).

In the FGD conducted in Cherwa area, one of the participants indicated that;

As a woman I feel a lot of pain because our political leaders do not care about us the ordinary people. They use a lot of insults that divide people along ethnic lines and make our lives unbearable, if you listen to the radio right now, it is like people are beating drums of war, leaders keep insulting one another as if we do not belong to one country. This kind of animosity has made people create imaginary enemies. People hate one another simply because of ethic politics (Cherwa FGD participant, $9^{\text {th }}$ April 2017).

In an interview with an official of the Nyakach Elders Development Group, the official contended that;

We are living in a sharply divided nation and all this is attributed to politics of division and self-centeredness. Look at the way positions are shared in the national government, it is simply unfair, and people from specific ethnic groups are always benefited at the expense of the rest of the country. Even the county governments are thriving on clanism and nepotism. Politicians have sowed seeds of discord among people from various ethnic groups which has made conflicts the order of the day in our communities (Official of the Nyakach Elders Development Group, $25^{\text {th }}$ March 2017).

The findings agree with Odongo (2011) who in reported that that political polarization and ethnic politics were the most serious effects of the conflicts in the study area. In further support of the findings Nyikuri (1997) opined that the clashes that took place in Kenya between 1991 and 1995 not only increased ethnic animosity and prejudice but also made ethnic politics a reality. The findings of this study were further supported by Dida (2012) who argued that politicians are characterized by caginess and biased attitudes in intervention of issues of conflicts between different ethnic groups. Lastly, the study's findings were in tandem the findings of Baxter (1994), whose studies established that the inter-ethnic conflicts that blemished Kenya throughout the onset of multiparty politics which was marred by killings and forceful evictions of people was somewhat attributed to incitements and ethnic stereotypes from politicians.

The study therefore makes it clear that politics has a huge influence on the recurrent conflicts in the study area. The type of politics in the study area is the politics of division meant to serve interest of politicians at the expense of peaceful coexistence between communities which keeps communities divided on the basis of their ethicized political identities.

\subsection{Socio-cultural Perceptions and Stereotypes amongst Ethnic groups in Nyakach and Sigowet Sub-counties of Western Kenya}

The study sought to establish the socio-cultural perceptions and stereotypes between ethnic communities in Nyakach and Sigowet sub-counties. The questions were asked depending on the respondent's ethnic background. The results were as designated in Table 4.1.

Table 4.1: Socio-cultural perceptions and stereotypes amongst Ethnic groups in Nyakach and Sigowet Subcounties of Western Kenya

Source: Field Data, 2017

\begin{tabular}{|c|c|c|c|c|}
\hline & \multicolumn{2}{|c|}{ Yes } & \multicolumn{2}{|c|}{ No } \\
\hline $\begin{array}{l}\text { Negative } \\
\text { Perception/ } \\
\text { Stereotype }\end{array}$ & $\begin{array}{l}\text { Frequenc } \\
\mathrm{y}\end{array}$ & $\begin{array}{l}\text { Percentag } \\
\mathrm{e}\end{array}$ & $\begin{array}{l}\text { Frequenc } \\
\mathrm{y}\end{array}$ & $\begin{array}{l}\text { Percentag } \\
\mathrm{e}\end{array}$ \\
\hline $\begin{array}{l}\text { Cattle } \\
\text { raiders }\end{array}$ & 214 & $72.4 \%$ & 82 & $27.6 \%$ \\
\hline $\begin{array}{l}\text { Idiosyncrati } \\
\text { c }\end{array}$ & 243 & $82.1 \%$ & 53 & $17.9 \%$ \\
\hline $\begin{array}{l}\text { Antagonisti } \\
\text { c }\end{array}$ & 272 & $92.2 \%$ & 24 & $7.8 \%$ \\
\hline Enemies & 69 & $23.4 \%$ & 227 & $76.6 \%$ \\
\hline
\end{tabular}

The household heads from both Nyakach and Sigowet Subcounties were asked whether they believed that the Luo or the Kipsigis communities were cattle thieves, the results revealed that $214(72.4 \%)$ of the respondent perceived members of either community as cattle raiders. These results were supported by findings from FGDs where it was it emerged that there was strong perception of cattle theft from both the Luo and the Kipsigis community. During the Luo men FGD in Sondu one of the participants argued that:

Cattle theft is practised by the Kipsigis as a cultural activity which means this is an institutionalised activity among the Kipsigis and therefore cattle rustling is seen tolerated and 
James Omondi Juma et al / The Nexus between Socio-Economic Environment and Recurrence of Inter-Ethnic Conflicts In Nyakach and Sigowet Sub-Counties of Western Kenya

encouraged by the Kipsigis culture. It is therefore obvious that stealing cattle is in the DNA of the Kipsigis (Sondu FGD

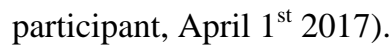

Another respondent from the same FGD added that;

Even we the Luo steal livestock from our own people. We have people who tend to be jealous of what other people have and therefore it would not be surprising for such people to organise for the stealing of livestock from the villages. In fact Nyithindo ma sikul otamo ma jonjaga e gweng kae e jokwoge dhok number one (some of these uneducated young men who smoke bang' in the village are the leading cattle thieves in this area). (Sondu FGD participant, April $1^{\text {st }}$ 2017).

In another FGD conducted in Tabaita one of the respondents exposed that

In as much we the Kipsigis are seen as cattle thieves by our Luo neighbours, the Luos themselves have also on many occasions been involved in cattle stealing especially when they claim to be tracing their stolen animals. Therefore livestock stealing happens in both communities (Tabaita FGD participant, April 20 2017).

The study results also showed that $273(82.1 \%)$ of the household heads viewed that members of either ethnic group as Idiosyncratic or individualistic. These findings were affirmed by the results from the four FGDs conducted in the study area. An FGD member from Cherwa indicated that;

The Kipsigis people love their own things and their own people. That is one thing that you cannot change about them. Even if your son marries a Kipsigis girl do not expect her do go against her community at any cost (Cherwa FGD participant, April $9^{\text {th }}$ 2017).

In an FGD conducted in Tabaita one respondents also signposted that

The Luos are our good neighbours lakini wanajipenda sana (but they love themselves too much) (Tabaita FGD participant, April 20 ${ }^{\text {th }}$ 2017).

The results in Table 4.1 further signposted that 272 (92.2\%) of the household heads from the two sub-counties perceived either community as antagonistic with only 24 (7.8\%) being of the contrary opinion. The findings from the household heads were also supported by the findings from FGDs. In the Cherwa FGD 6 out of 10 of the participants were of the opinion that the Kipsigis were antagonistic. One of the FGD participants signposted that;

The Kipsigis youths are very hostile. They normally attack people using spears. That can only be done by someone with the motive to kill (Cherwa FGD Participant, $9^{\text {th }}$ April 2017).

In another FGD, conducted in Tabaita 7 out of 10 of the participants opined that the Luos were antagonistic. One of the participants noted that;

If you want to know that the Luos are hostile, wait until there is a political problem in the country. They will stone and even burn vehicles heading to Kericho and in many cases end up injuring people using stones and other crude weapons (Tabaita FGD participant, April 20 $0^{\text {th }}$ 2017).

The findings of the study further revealed that the Luo and the Kipsigis do not perceive one another as enemies supported by $227(76.6 \%)$ of the household heads. These findings were also supported by the respondents from each of the four FGD who stated that in as much as there were disagreements between the two communities, they were not enemies. One of the participants from the Sondu FGD noted that;

The Kipsigis and the Luo have differences but we are not enemies. We live together as good neighbours do. Our daughters and sons inter-marry and we share many other things in common (Sondu FGD participant, April $1^{\text {st }}$ 2017).

\subsection{Socio-economic drivers of conflicts in Nyakach and} Sigowet Sub-counties of Western Kenya

The study sought to establish the extent to which the respondents agreed with the following socio-economic concerns as drivers of conflicts in Nyakach and Sigowet subcounties of western Kenya; poverty, youth unemployment, land and boundary issues and ethnic mistrust. The Results are as indicated in Figure 4.4

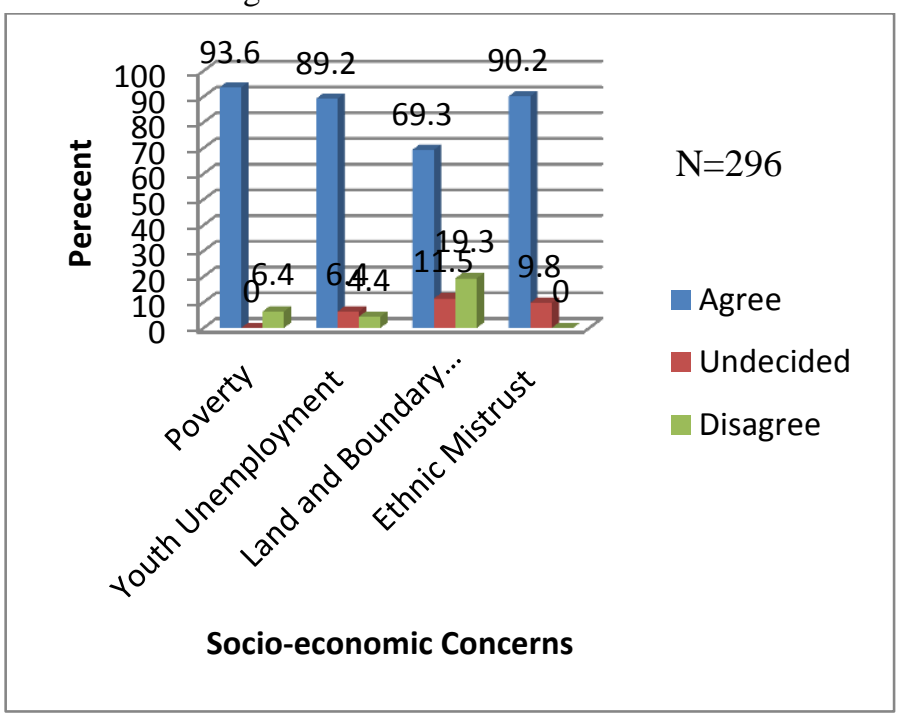

Figure 4.4: Socio-economic concerns for communities in Nyakach and Sigowet Sub-counties of Western Kenya

\section{Source: Field Data (2017)}

\subsubsection{Poverty}

The Study sought to establish the household head's opinion on poverty as driver of conflicts in the study area. The result in figure 4.4 indicated that out of 296 household heads $277(93.6 \%)$ of the respondents agreed compared that poverty was a serious concern as compared to a paltry $19(6.4 \%)$ who were of the contrary opinion. Poverty which is mainly associated with lack of proper means of subsistence among community members was identified to be a major factor that has often created discord among community members with people competing for the scarce resources to meet their daily needs. Poverty has pushed many people especially young people who do not have jobs to be involved in crimes such as cattle theft which the study established as one of the major causes of conflicts in the study area. These findings were supported by results from key informant interviews where one of the respondents noted that;

The high poverty levels in among the youths coupled with lack of jobs for the youths makes them look for the easy ways of to survive, many of these jobless youths who only have basic education are the ones always involved in stealing 
James Omondi Juma et al / The Nexus between Socio-Economic Environment and Recurrence of Inter-Ethnic Conflicts In Nyakach and Sigowet Sub-Counties of Western Kenya

animals from their community or from neighbouring communities to get money (Interview with Assistant Chief Agoro East, $15^{\text {th }}$ March 2017).

These findings of the study were consistent with the assertions made by Aremu (2010) and Ikejiaku (2012) who argue that ethnic conflicts are caused by social injustices which lead to poverty as a result of the denial of basic needs to the populace. The findings are further supported by Ted Gurr's relative deprivation theory which contends that ethnic conflicts are due to ethnic group's competition and struggle to have access to economic resources and power (Gurr, 1970). As far as group differences and inequalities are concerned, relative poverty, not absolute poverty, matters. For the avoidance of conflicts, what matters is sharing resources of all kinds across all communities; shared poverty do not lead to conflict, however, where a society is poor but some groups succeed in securing a disproportionate share of resources, there may be a predisposition to conflict (Brown \&Stewart, 2015). In Nepal for example, the Caste has been used to marginalize poor communities leading to deep rooted inequality and economic deprivations.

\subsubsection{Youth Unemployment}

The study sought to establish the extent to which youth unemployment was a driver of conflicts in the study area. The results in figure 4.4 indicated that out of 296 respondents 264 $(89.2 \%)$ agreed that youth unemployment was a major driver of conflicts as compared to $13(4.4 \%)$ who disagreed. Youth unemployment makes young people to easily engage in acts that can easily jeopardize peace among members of the community such as crimes, or being involved in politically instigated violence which may in turn lead to a situation of inter-ethnic conflicts. In 2007/2008, most of the participants in the post-election violence were unemployed youths from various parts of the country (Akinyi-Dar et. al., 2011). Most of these youths were involved in looting and breaking into houses to steal mainly because they did not have an alternative source of income. With the Kenya unemployment rate standing at $39.1 \%$ and projected to go higher, according to the United Nation human index (HDI) 2016 report, the unemployment problem is likely to cause more complex problems (UNDP, 2016).

These findings agreed with KNCHR (2014) report which indicated that unemployed youths served as a strong push factor for radicalization, the report further asserts that, youth unemployed, coupled with perceptions of real or imagined systemic marginalization, contributed to youth vulnerability and easy proclivity to conflicts and other terror related activities. Brown \&Stewart, (2015) in further support of the findings indicated that when people especially young men, lack employment or fruitful income-earning opportunities; the moderate "riches" conferred by conflicts may offer them an attractive option. However, expanding employment opportunities for young men is generally important in preventive policy for conflicts, and especially for post-conflict societies. Brown (2010) further asserted that high unemployment is frequently associated with outbreaks of conflict, for example, in Sri Lanka and Algeria, lack of opportunities in general, is a common feature triggering conflict breaks out, akin to this, the pre-conflict situation in Sierra Leone has not been an exception

\subsubsection{Ethnic Mistrust}

The Study sought to establish the extent to which ethnic mistrust was a concern among communities living in the study area. The results as shown in Figure 4.4 indicated that out of the 296 household heads $267(90.2 \%)$ agreed ethnic mistrust was a serious concern while $29(9.8 \%)$ expressed a contrary opinion. Inter-ethnic mistrust mainly between the Luo and the Kipsigis in the study area is caused by the repeated incidences of the cattle rustling and attacks that lead to death and displacement of people from time to time. Repeated incidences of violence by one ethnic group targeting another ethnic group tends to lead to the situation where each ethnic group does not trust the other thereby leading to a situation where members of each ethnic community look at the other as a common enemy. As Gurr (2000) opines that, once conflicts breaks out, ethnic identities and hatred tend to become cemented in ways that make cooperation and coexistence between the groups even more difficult, and these are the conflicts that are likely to recur over time.

In this sense, the findings of this study agreed with the argument of Kumssa, et al (2009) who reported that beyond the physical effects, ethnic conflicts negatively affects the inter-communal relations. The study also concurred with Schilling, et al. (2012) further reported that, community members of both Pokot and Turkana have expressed strong negative feelings and distrust towards the other group. This kind of distrust reduces the motivation and the capability of the communities to choose a cooperation which is a prerequisite for peaceful and effective resource sharing. Relationship between communities further deteriorates when the raids are violent and include incidences of rape and abduction of women (Schilling, et al., 2012). In response to the ever growing inter-ethnic mistrust and the incessant hostile attacks, a community may choose the path of retaliation which further fuels the conflict.

\subsubsection{Land and Boundary issues}

The sought to establish the extent to which and land and boundary issues were a concern in the study area. The results in Figure 4.4 indicated that $205(69.3 \%)$ of the respondents agreed that Land and boundary issues were significant concerns and drivers of conflicts while 57 (19.3\%) disagreed.

The land question was greatly supported by results from FGDs. In an FGD held in Sondu 9 out of 10 of the participants opined that land was one of the major issues in the area especially along the boundary of the two sub-counties. It was specifically pointed out by one of the respondents that people who had bought land along the border on the Sigowet side were frequently attacked and their houses burnt during the clashes.

These findings are consistent with the Kenya Red Cross (2008) report which signposted that contested boundaries have 
James Omondi Juma et al / The Nexus between Socio-Economic Environment and Recurrence of Inter-Ethnic Conflicts In Nyakach and Sigowet Sub-Counties of Western Kenya

led to the burning of houses, hotels and a school in Chepilat [6] Brown, G.K (2010) "The Political Economy of area, these incidences were geared towards some forms of Secessionism: Identity, Inequality and the state". Bath Papers in International Development, Working Paper No. 9, Centre for Development studies, University of Bath.

ethnic cleansing. Akinyi-Dar et al., (2011) in further support of the findings indicates that inter and intra community land disputes were common due to scarcity of land as well as lack of clear demarcation of boundaries which makes community members to have mutual agreements on the boundaries, a factor that makes land related conflicts difficult to resolve. In Sondu areas where the land problem is common, the Kipsigis believe that the Kisii and Luo have encroached into their land and hence they have the duty to defend the land. The Luo and the Kisii on the other hand argue that they have purchased the land legally and therefore must be allowed to go on with their business (Akinyi-Dar et. al., 2011). This has often been a major factor for the recurrence of these conflicts with each community fighting for the land.

\subsection{Conclusion}

The study concludes that that poverty, unemployment, ethinicization of politics and unequal distribution of resources and opportunities were the major socio-economic drivers that contributed significantly to recurrence of the inter-ethnic conflicts in the study area. Additionally, ineffective methods of conflict management, socio-cultural stereotypes and impunity by the perpetrators of the conflicts have made these conflicts incessant.

\subsection{Recommendation}

The study recommends improved sharing of resources and opportunities in the study area both at national and county levels to ensure economic empowerment of people in the area. Additionally, the study recommends that political leaders be actively involved in the conflict management to avoid issues of ethnicization of politics as a way to promote peaceful coexistence between communities.

\section{References}

[1] Akinyi-Dar, N. P., Kabongah G. O., Otieno O., Leo P., Kamau M., Onyango, M., Wepundi, M. \& Obiri, J. (2011). The Invisible Violence in Kenya: A Case Study of Rift Valley and Western Regions, Nairobi Kenya: Konrad Adenauer-Stiftung

[2] Aremu, J. O. (2010). Conflicts in Africa: Meaning, Causes, Impact and Solution. African

Research Review. An International Multi-Disciplinary Journal, $\quad$ Ethiopia Vol. 4 (4), available at www.ajol.info/index.php/afrrev/article/download/69251/57 $\underline{286}$

[3] Bahgat, K., Barrett, G., Dupuy, K. Gates, S. \& Hillesund S. (2017). Inequality and Armed Conflict: Evidence and Data. Peace Research Institute Oslo.

[4] Baxter, P.T.W. (1994). Ethnicity and Conflict in the Horn of Africa, James Currey, London.

[5] Brown, K. G. \& Stewart F. (2015). Economic and Political Causes of Conflict: An Overview and Some Policy Implications. CRISE WORKING PAPER No. 81 Queen Elizabeth House, University of Oxford. Mansfield Rd.UK

[7] Burton, J. (1990). Conflict: Resolution and Prevention. New York: St. Martin's Press.

[8] Dida, G. (2012). Determinants of inter-tribal Conflicts in Godamoji Division, Marsabit; unpublished Master Thesis. University of Nairobi.

[9] Does, A. (2013). Inclusivity and Local Perspectives in Peacebuilding: Issues, Lessons, Challenges.

[10] Geneva Peace building Plaform. Paper No 8. Retrieved fromhttp://www.daghammarskjold.se/wpcontent/uploads/2014/08/PP-08- Inclusivity-of-LocalPerspectives-in-PB-July-2013.pdf on 30/5/2016

[11] Gurr, T. (1970). Why Men Rebel. Princeton.

[12] Gurr, T. R. (2000). Peoples Versus States: Minorities at Risk in the New Century. Washington, DC: United States Institute of Peace.

[13] Ikejiaku B. V. (2012.) Poverty-Conflict nexus: The Contentious issue revisited. European Journal of Sustainable development 1,2 127-15 ISSN: 2239-5938.

[14] Kenya Red Cross Report, (2014).Nyakach Ethnic Conflict Updates on 11th March 2014. Retrieved on $10^{\text {th }}$ March, 2016 at www.reliefweb.int/report/kenya

[15] Kipkemoi, J.L. (2015). Factors Influencing interethnic conflicts in Kuresoi North Sub-county: Nakuru County Kenya. Unpublished Master Research. University of Nairobi.

[16] KNCHR. (2014).Are we under Siege? The state of Security in Kenya. An Occasional Report (20102014). Retrieved from http://www.ke.undp.org/content/dam/kenya/docs/Democra tic\%20Governance/State $\% 20$ o f\%20Security\%20in\%20Kenya\%20-

Occassional\%20Report.pdf

[17] Kumssa, A., Jones J.F, \& Williams J.H. (2009).Conflict and human security in the North Rift and North Eastern Kenya. International Journal of Social Economics, 36(10):1008-1020.

[18] Mooney L.A , Knox, D. \& C Schacht(2007). Understanding Social Problems ( $5^{\text {th }} \quad$ edition).

Belmont, CA. Thomson Wadsworth.

[19] Mugenda, A. \& Mugenda, O. (2003). Research Methods: Quantitative and Qualitative Approaches. Acts Press: Nairobi

[20] Nyongesa H.W., Wakhungu J.W. \& Maragia S. (2016). Strategic Humanitarian Interventions during the Ethnic Conflict Period in Sigowet and Nyakach Sub Counties of Kenya: Pupils' Perspective. International Journal of Recent Research in Social Sciences and Humanities (IJRRSSH) Vol. 3, Issue 2, pp: (44-52)

[21] Nyukuri, B. K., (1997). The Impact of Past and Potential Ethnic Conflicts on Kenya's Stability and Development. Paper prepared for the USAID Conference on 
James Omondi Juma et al / The Nexus between Socio-Economic Environment and Recurrence of Inter-Ethnic Conflicts In Nyakach and Sigowet Sub-Counties of Western Kenya

Conflict Resolution in the Greater Horn of Africa June,

1997. Retrieved on 15 November 2015

at

http://payson.tulane.edu/conflict/Cs\%20St/BARASFIN1.ht

$\underline{\mathrm{ml}}$

[22] Odongo D.A (2011). Inter-ethnic coexistence among the Luo, Kipsigis and Kisii Communities in Sondu Area Kenya. Unpublished Masters Research Paper. University of Nairobi.

[23] Oucho, J.O. (2008). Undercurrents of Post-Election Violence In Kenya: Issues In The Long- Term Agenda. School of Journalism Press and Population Studies and Research Institute: University of Nairobi.

[24] Safer World Briefing. (2015). Kisumu County Conflict Analysis. LPCI, NCCK. Retrieved on 18 March 2016 at http://mercury.ethz.ch/serviceengine/Files/.../kisumuconflict-analysis.pdf

[25]Schilling, J., Opiyo, F.E. \& Scheffran, J. (2012). Raiding pastoral livelihoods: Motives and effects of violent conflict in north-western Kenya. Pastoralism 2: 25.

[26] UNDP. (2016). Human Development Report 2016: Human Development for everyone. UNDP. New York. USA. Retrieved on $10^{\text {th }}$ February 2018 from http://hdr.undp.org/sites/default/files/2016_human development_report.pdf 